\title{
Characterization of R.F. Magnetron Sputtered Vanadium Oxide Thin Films and Intercalation of Lithium in the Oxide Films
}

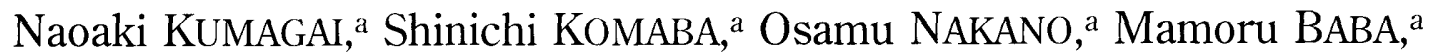 \\ Henri GROULT, ${ }^{b}$ and Didier DEVILLIERs ${ }^{b}$
}

\author{
aFaculty of Engineering, Iwate University (4-3-5, Ueda, Morioka 020-8551, Japan) \\ Université Pierre ei Márie Curie, Laboratory LI2C-Electrochimic-CNRS UMR-7612 (4 Place Jussieu, 75252, Paris, \\ France)
}

Received August 1, 2003 ; Accepted January 28, 2004

\begin{abstract}
Vanadium oxide films were deposited by r.f. magnetron sputtering technique on SUS 304 stainless steel substrates in $\mathrm{Ar}+\mathrm{O}_{2}$ atmosphere using $\mathrm{V}_{2} \mathrm{O}_{5}$ target. The films obtained were characterized by X-ray diffractometry and scanning electron microscopy. The XRD and SEM observations show that the crystallographic orientation and surface morphology of the vanadium oxide films are changed with film thickness. For the thin film with thickness of $450 \mathrm{~nm}$ the $\mathrm{V}_{2} \mathrm{O}_{5}$ phase with the ab plane parallel to the substrate is formed, resulting in a highly smooth surface, while for thicker films with thickness of $1.0 \sim 4.0 \mu \mathrm{m}$ the $\mathrm{V}_{2} \mathrm{O}_{5}$ phase with the ab plane perpendicular to the substrate is formed, giving a considerably rugged surface. The vanadium oxide films undergo a reversible lithium intercalation and deintercalation process, and the thicker film $(4.0 \mu \mathrm{m})$ showed more distinct stepwise discharge profile than the thin film $(0.45$ $\mu \mathrm{m})$. The kinetics of intercalation process of lithium into the $\mathrm{V}_{2} \mathrm{O}_{5}$ film was studied using an electrochemical transient technique, deducing kinetic parameters such as chemical and lithium component diffusion coefficients and activation energy for lithium diffusion.
\end{abstract}

Key Words : Vanadium Pentoxide Thin Film, R.F.-Magnetron Sputtering, Electrochemical Lithium Intercalation

\section{Introduction}

One of the prospective application for solid state lithium batteries would be as on-chip power backup where the battery is an integral part of an integrated circuit device. Such batteries should be made with conventional thin-film techniques such as vapor deposition or sputtering in order to meet the quality and production requirements of the IC industry. Among many transition metal oxides, vanadium pentoxide $\left(\mathrm{V}_{2} \mathrm{O}_{5}\right)$ has kept much attention since it exhibits good electrochemical performances for lithium insertion/deinsertion reaction. ${ }^{1-3}$ ) In addition to the attractive electrochemical properties of $\mathrm{V}_{2} \mathrm{O}_{5}$, much attention has been paid to such thin film electrode material in all-solid-state batteries, since several techniques can be used for the synthesis as thin films. Among them, one can mention thermal evaporation, ${ }^{4,5)}$ sol-gel coating $^{6)}$ pulse laser deposition, ${ }^{7)}$ radio frequency (r.f.) sputtering, ${ }^{8-10)}$ atomic layer chemical vapor deposition ${ }^{11,12)}$ and chemical vapor deposition. ${ }^{13)}$

We previously reported the preparation and characterization of $\mathrm{V}_{2} \mathrm{O}_{5}$ thin film by r.f. sputtering and the lithium intercalation in the thin film, ${ }^{14)}$ and furthermore the fabrication and electrochemical characteristics of all-solid-state lithium-ion batteries using r.f. magnetron sputtered $\mathrm{V}_{2} \mathrm{O}$ thin films for both negative and positive electrodes. ${ }^{15}$ It was found that the morphology, structure and orientation of the vanadium oxide films are varied by the condition of sputtering deposition. ${ }^{14,15)}$

In this work, the orientation and morphology of $\mathrm{V}_{2} \mathrm{O}_{5}$ thin films with various film thicknesses, which were pre- pared by r.f. magnetron sputtering, have been investigated by X-ray diffractometory (XRD) and scanning electron microscopy (SEM), and the electrochemical lithium intercalation in $\mathrm{V}_{2} \mathrm{O}_{5}$ thin films has been examined. Furthermore, the variation in the crystal lattice of $\mathrm{V}_{2} \mathrm{O}_{5}$ thin film has been investigated as a function of lithium concentration in the oxide, and the kinetics of lithium intercalation reaction in the oxide thin films has been investigated, deducing several kinetic parameters for lithium intercalation.

\section{Experimental}

Vanadium oxide films were deposited on a SUS 304 stainless steel substrate by r.f. magnetron sputtering using a $\mathrm{V}_{2} \mathrm{O}_{5}$ target in a mixed $\mathrm{Ar} / \mathrm{O}_{2}$ atmosphere. The r.f. power and the total gas pressure were $1.5 \mathrm{~kW}$ and $1 \times$ $10^{-2}$ Torr. The base pressure in the sputtering chamber was $10^{-6}$ Torr. The ratio of $\mathrm{Ar} / \mathrm{O}_{2}$ was $87 / 13$, which was adjusted by the argon flow rate of 30 standard cubic centimeters (sccm) and the oxygen flow rate of $4.5 \mathrm{sccm}$. The thickness of the vanadium oxide film was controlled by deposition time and measured by observing interference fringes using a multiple beam interferometer (Mizojiri, type II) and by using a step-profiler (VEECO Instrument Inc, DEKTAK 35 ST type). The weight of the vanadium oxide layer was calculated using the density of $\mathrm{V}_{2} \mathrm{O}_{5}\left(3.36 \mathrm{~g} \mathrm{~cm}^{-3}\right)$. The characterization of the r.f. sputtered vanadium oxide films was carried out by means of scanning electron microscopy (Hitachi S-450), and X-ray diffractometory (Rigaku Denki Geiger flex 20B, $\mathrm{Cu} \mathrm{K} \alpha$ 
radiation). To investigate the electrochemical properties, an electrochemical cell was constructed by coupling the oxide film electrode with a lithium counter electrode and a lithium reference electrode in a $1 \mathrm{M} \mathrm{LiClO}_{\text {t-propylene }}$ carbonate (PC) electrolyte. The active surface area of vanadium oxide films for electrochemical test was $1 \times 1 \mathrm{~cm}^{2}$. A glass beaker-type cell was used as an electrochemical cell. The galvanostatic charge-discharge tests were carried out with the Hokuto Denko charge-discharge system (HJ-201 type) at constant current density of $0.01 \mathrm{~mA}$ $\mathrm{cm}^{-2}$ in the potential window from $1.2 \mathrm{~V}$ to $4.5 \mathrm{~V}$ vs. $\mathrm{Li} /$ $\mathrm{Li}^{+}$at $25 \pm 2^{\circ} \mathrm{C}$. During the initial discharge, the titration curve was generated by passing a known amount of charge with a current density of $0.01 \mathrm{~mA} / \mathrm{cm}^{2}$ through the cell, and then allowing the system to reequilibrate for more than $24 \mathrm{~h}$ at $25^{\circ} \mathrm{C}$. This was repeated many times to obtain a plot of quasi-open-circuit potential (OCV) vs. the $\mathrm{x}$ value in $\mathrm{Li}_{\mathrm{x}} \mathrm{V}_{2} \mathrm{O}_{5}$. All the measurements were carried out in oxygen-free, water vapor-free, argon filled dry box.

\section{Results and Discussion}

3. 1 Characterization of r.f. magnetron sputtered vanadium oxide films

The X-ray diffraction patterns of $\mathrm{V}_{2} \mathrm{O}_{5}$ films as deposited by r.f. magnetron sputtering are shown in Fig. 1 as a function of film thickness. The crystal structure of $\mathrm{V}_{2} \mathrm{O}_{5}$ having an orthorhombic structure (Pmmn, $\mathrm{a}=11.51 \AA, \mathrm{b}$ $\left.=3.559 \AA, \mathrm{c}=4.371 \AA, Z=2^{16}\right)$ ) is given Fig. 2 .

As seen in the figure, a weak and broad peak appears at $2 \theta=$ around $20^{\circ}$ for the film thickness of $450 \sim 1090$ $\mathrm{nm}$. This peak can be indexed to be $(00 l)$ reflection of $\mathrm{V}_{2} \mathrm{O}_{5}$. The preference for $(00 l)$ reflection in the films indicates that the crystallites of the film grow with the cdirection perpendicular to the substrate plane, i.e., prefentially with the ab plane paralled to the substrate. In the thicker film above $1090 \mathrm{~nm}$, however, (110) and (220) peaks appear at $2 \theta=26.2^{\circ}$ and $50.5^{\circ}$. The intensity of these peaks increases with increasing the film thickness to $4030 \mathrm{~nm}$. The strong $(h k O)$ reflections for the

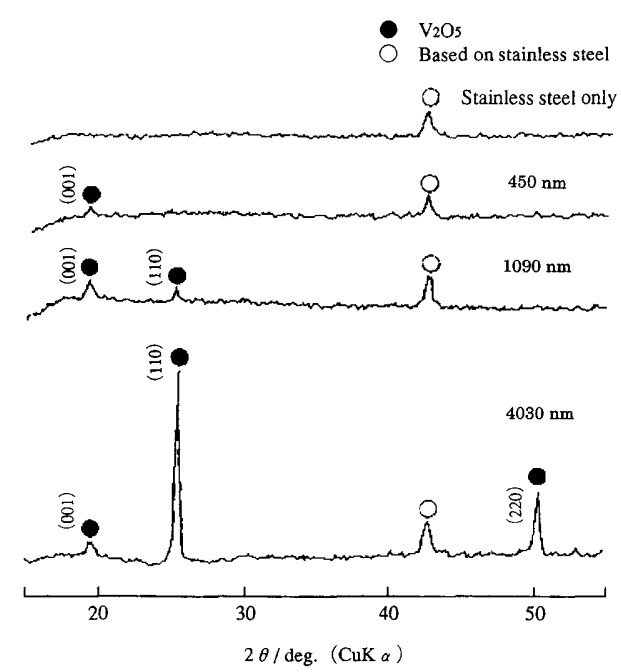

Fig. 1 X-ray diffraction patterns of vanadium oxide films on stainless steel substrate as deposited by r.f. magnetron sputtering. Film thickness : 450, 1090 and $4030 \mathrm{~nm}$.
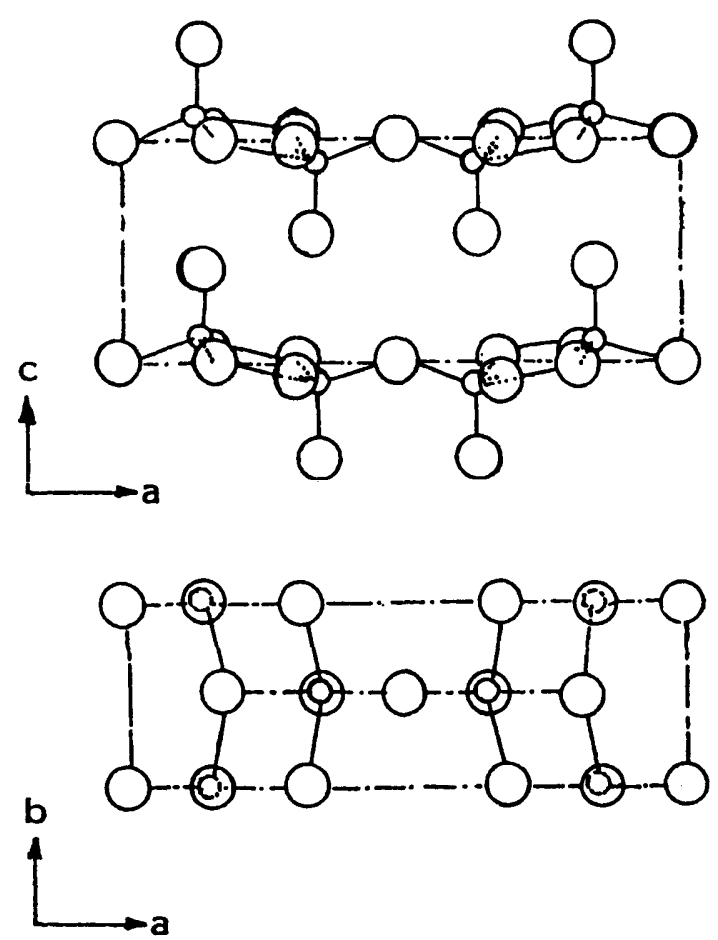

Fig. 2 Crystal structure of $\mathrm{V}_{2} \mathrm{O}_{5}$. Key : (small circle) V atom; (large circle) $\mathrm{O}$ atom.

thicker films reveal that $\mathrm{V}_{2} \mathrm{O}_{5}$ crystallites in the thin films grow with the c-direction parallel to the substrate plane, resulting in a highly oriented $\mathrm{V}_{2} \mathrm{O}_{5}$ film with the ab plane perpendicular to the substrate. Thus, the XRD measurements reveal that the increase of film thickness changes the crystallographic orientation of the $\mathrm{V}_{2} \mathrm{O}_{5}$ film. The SEM photographs of the $\mathrm{V}_{2} \mathrm{O}_{5}$ films with different thick-
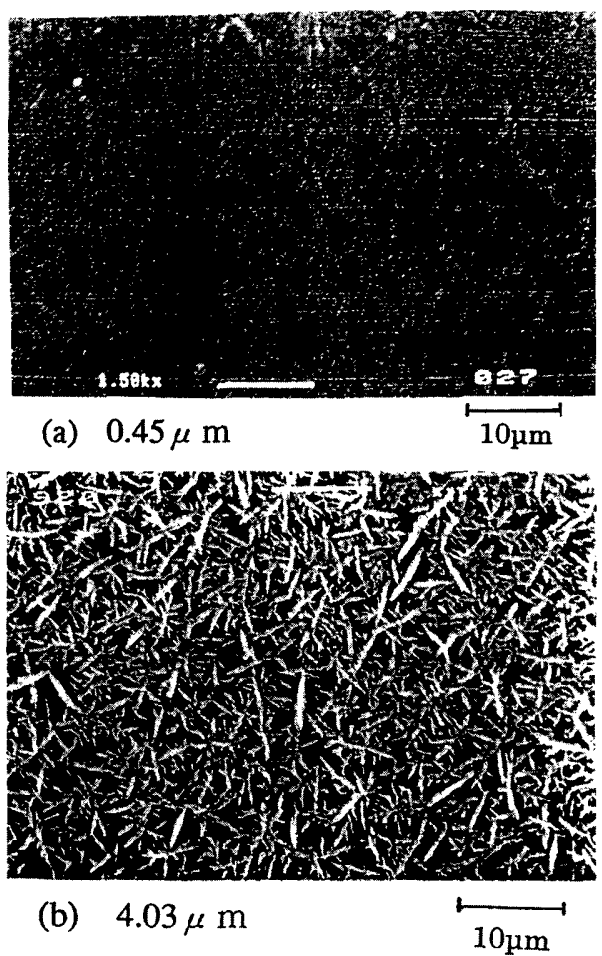

Fig. 3 SEM photographs of vanadium oxide films with thicknesses of (a) $0.45 \mu \mathrm{m}$ and (b) $4.03 \mu \mathrm{m}$ as deposited by r.f. magnetron sputtering. 
nesses fabricated by r.f. magnetron sputtering are given in Fig. 3. As can be seen in the photographs, fairly smooth surface is observed with the film thickness of $450 \mathrm{~nm}$. For the thick film (Fig. 3b), however, a rugged surface consisting of many fine microcrystals is observed which is superimposed on the smooth surface texture. This change in morphology may be related to the orientation of $\mathrm{V}_{2} \mathrm{O}_{5}$ phase, that is, the ab plane of the $\mathrm{V}_{2} \mathrm{O}_{5}$ phase in such thin film (450 nm thickness) is grown parallel to the substrate, while the ab plane in thicker film $(4.03 \mu \mathrm{m})$ is grown perpendicular to the substrate.

3. 2 Electrochemical characteristics of r.f. magnetron sputtered $\mathrm{V}_{2} \mathrm{O}_{5}$ film

The initial discharge and recharge curves of the r.f. magnetron sputtered films with different thicknesses in the range from $450 \mathrm{~nm}$ to $4030 \mathrm{~nm}$ are shown in Fig. 4 . In any $\mathrm{V}_{2} \mathrm{O}_{5}$ film, the stepwise discharge profile with main two plateaus at around $3.3 \mathrm{~V}$ and $2 \mathrm{~V}$ vs. $\mathrm{Li} / \mathrm{Li}^{+}$is observed at the initial discharge. The discharge capacity at the 1st step with around $3.3 \mathrm{~V}$ vs. $\mathrm{Li} / \mathrm{Li}^{+}$is about $70 \mathrm{mAh} \mathrm{g}^{-1}$ and that at the 2nd step with around $2 \mathrm{~V}$ is about $130 \mathrm{mAh} \mathrm{g}^{-1}$ in the oxide film with $450 \mathrm{~nm}$ thickness, decreasing gradually with increasing the film thickness up to about $150 \mathrm{mAh} \mathrm{g}^{-1}$. However, more distinct discharge behaviors, consisting of four plateaus, are seen with increasing the film thickness. This would be due to higher crystallinity and higher orientation with ab plane perpendicular to the substrate, as seen in the XRD patterns (Fig. 1). Figure 5 shows the initial discharge and charge-discharge curves of $\mathrm{V}_{2} \mathrm{O}_{3}$ films with the thicknesses of (a) $0.45 \mu \mathrm{m}$ and (b) $4.03 \mu \mathrm{m}$. In the thinner $\mathrm{V}_{2} \mathrm{O}_{5}$ film with the $0.45 \mu \mathrm{m}$ thickness, the discharge capacity decreases by about $20 \sim 25 \%$ after the first discharge, and stable capacity retention was observed after 5 cyclings. On the other hand, although the thicker oxide film with $4.03 \mu \mathrm{m}$ shows a lower initial discharge capacity of about $150 \mathrm{mAh} / \mathrm{g}$, this discharge capacity was maintained during above 5 cyclings, and a better cyclability was obtained. As seen in Fig. 5 , the shape of the second and 5th discharge curves is quite different from that of the first discharge curves. It has been reported in our

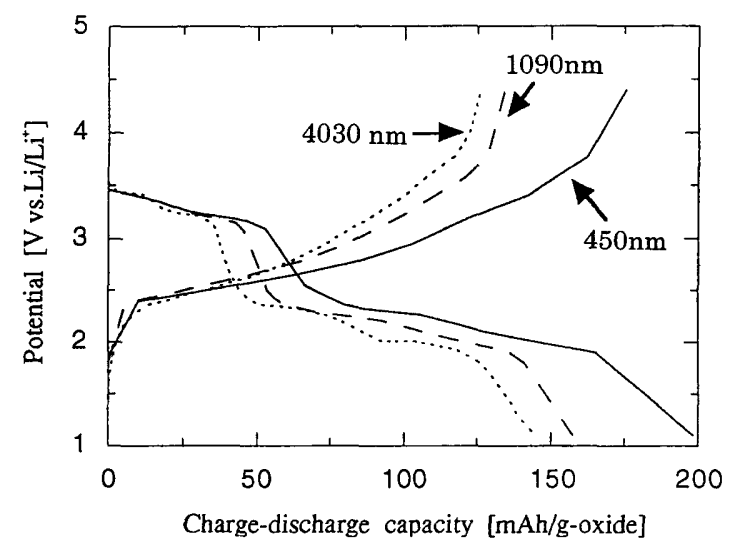

Fig. 4 Initial discharge and recharge curves of vanadium oxide films with different thicknesses as deposited by r.f. magnetron sputtering. Current density : $0.01 \mathrm{~mA} / \mathrm{cm}^{2}$, Film thickness : 450, 1090, and $4030 \mathrm{~nm}$.
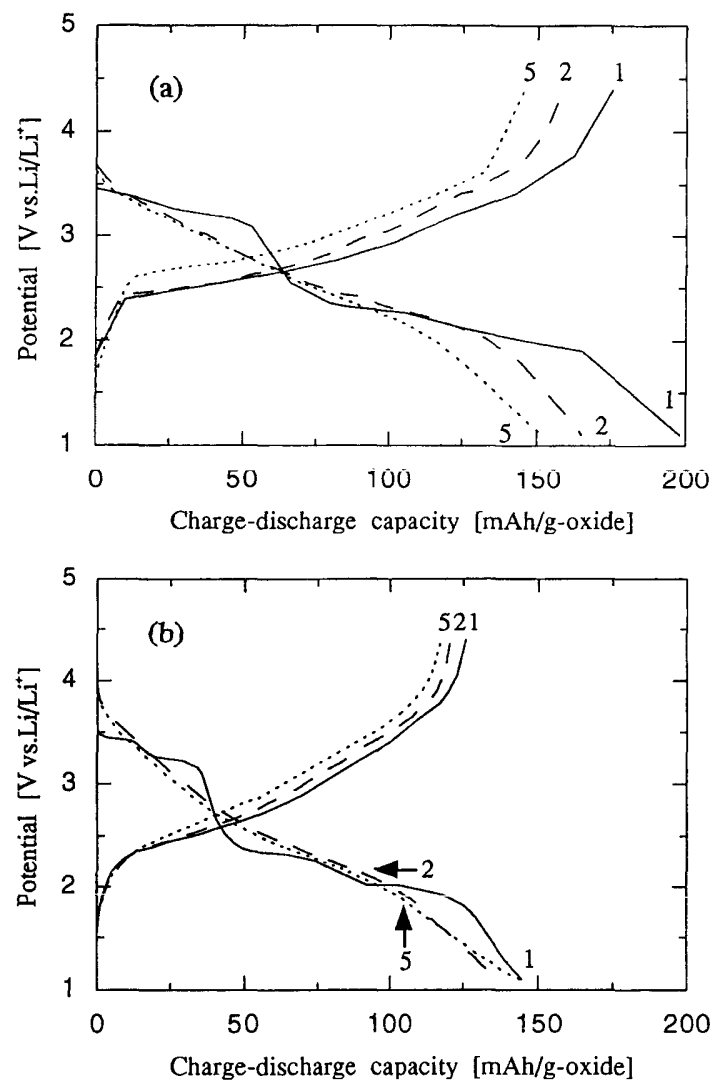

Fig. 5 Charge-discharge cyclic curves of vanadium oxide films with thicknesses of (a) $0.45 \mu \mathrm{m}$ and (b) $4.03 \mu \mathrm{m}$ as deposited by r.f. magnetron sputtering. Current density : 0.01 $\mathrm{mA} / \mathrm{cm}^{2}$.

previous papers ${ }^{1,2,14}$ that when crystalline $\mathrm{V}_{2} \mathrm{O}$, powder and $\mathrm{V}_{2} \mathrm{O}_{5}$ thin film prepared by r.f. sputtering were discharged below $2 \mathrm{~V}$, an irreversible change was usually observed in the shape of the charge-discharge curves, which was associated with an irreversible structural change involving a phase transformation to $\gamma-\mathrm{V}_{2} \mathrm{O}_{5}{ }^{1{ }^{17}}$ Thus, the irreversible change in the discharge curve can be related to an irreversible phase transformation.

When the magnetron sputtered film with thickness of $450 \mathrm{~nm}$ was charge-discharge cycled with a higher discharge cut-off potential of $2.8 \mathrm{~V}$ vs. $\mathrm{Li}^{\prime} / \mathrm{Li}^{+}$and charge cut-off potential of $4.5 \mathrm{~V}$, the discharge capacity of about $55 \mathrm{mAh} \mathrm{g}^{-1}$ was maintained during 100 cyclings, although the capacity decreased by about $10 \%$ after 100 cycles. This indicates that the system is reversible during long term cycling within the 1st plateau.

3. 3 Structural change and lithium diffusion characteristics in $\mathrm{V}_{2} \mathrm{O}_{5}$ thin film with lithium intercalation

Figure 6 shows XRD patterns of $\mathrm{V}_{2} \mathrm{O}_{5}$ film with thickness of $4.03 \mu \mathrm{m}$ as deposited by r.f. magnetron sputtering and its discharge products, $\mathrm{Li}_{x} \mathrm{~V}_{2} \mathrm{O}_{\overline{3}}$. As seen in the figure, the intensity of the (110) and (220) peaks decreases and is getting broad with an increase in lithium content ( $\mathrm{x}$ in $\mathrm{Li}_{\mathrm{x}} \mathrm{V}_{2} \mathrm{O}_{5}$ ). Furthermore, it should be noticed that these peaks are shifted to higher $2 \theta$ positions with an increase in lithium content, finally disappeaing at above $x=0.8$. Fig. 7 exhibits the variation in the layer spacing of (110) peak $\left(\mathrm{d}_{110}\right)$ in Fig. 6, as a function of $\mathrm{x}$ - 


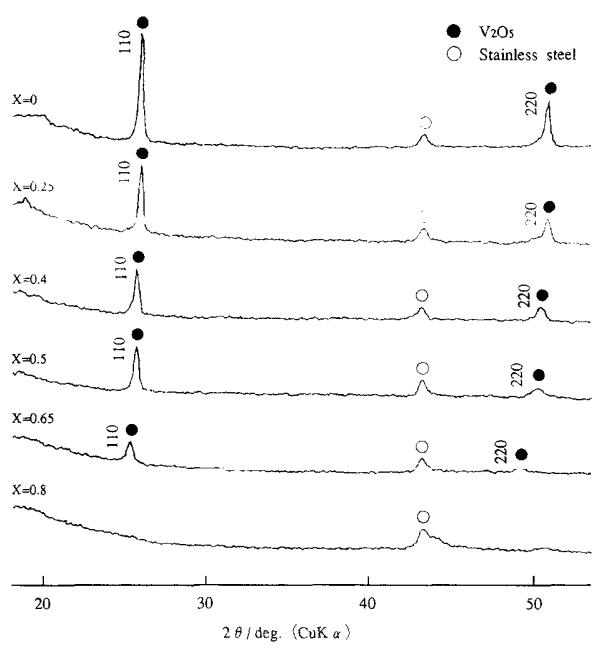

Fig. 6 X-ray diffraction patterns of $\mathrm{V}_{2} \mathrm{O}_{5}$ film and its discharge products $\mathrm{Li}_{\mathrm{x}} \mathrm{V}_{2} \mathrm{O}_{5} . \mathrm{V}_{2} \mathrm{O}_{5}$ films as deposited with thickness of $4030 \mathrm{~nm}$ were used.

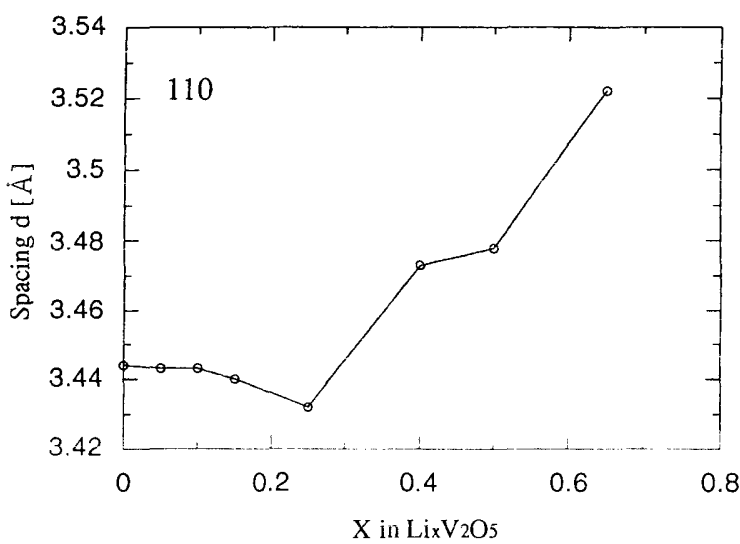

Fig. 7 The variation in the layer spacing of (110) diffraction line of orthorhombic $\mathrm{V}_{2} \mathrm{O}_{5}$ as a function of $\mathrm{x}$ in $\mathrm{Lix}_{\mathrm{x}} \mathrm{V}_{2} \mathrm{O}_{5} . \mathrm{V}_{2} \mathrm{O}_{5}$ films as deposited with thickness of $4030 \mathrm{~nm}$ were used.

value in $\mathrm{Li}_{\mathrm{x}} \mathrm{V}_{2} \mathrm{O}_{5}$. The spacing remains almost constant until $\mathrm{x}=0.3$, but in the range from 0.4 to 0.6 the spacing increases with $x$-value, indicating the lattice expansion along the c-direction parallel to the substrate.

In order to obtain the information about the diffusion behavior of lithium ions in the crystal lattice of vanadium oxide layer, the chemical diffusion coefficients for lithium ions in the r.f. magnetron sputtered $\mathrm{V}_{2} \mathrm{O}_{5}$ film were measured as a function of $\mathrm{x}$-value in $\mathrm{Li}_{\mathrm{x}} \mathrm{V}_{2} \mathrm{O}_{5}$ by using the current-pulse relaxation technique. ${ }^{18)}$ The chemical diffusion coefficients, $\tilde{D}$, were deduced from the following formula for the time dependence of the transient voltage $(\Delta E)$;

$$
\Delta E=\mathrm{mV} i \tau / \mathrm{FA}(\pi \bar{D} t)^{12}
$$

where $\mathrm{m}$ is the slope of open-circuit potential / $\mathrm{x}$ in $\mathrm{Li}_{\mathrm{x}} \mathrm{V}_{2} \mathrm{O}_{5}$ curve given in Fig. $8, \mathrm{~V}$ is the molar volume $\left(54.1 \mathrm{~cm}^{3} \mathrm{~mol}^{-1}\right), i$ is current pulse, $\tau$ is the duration of the pulse, and $\mathrm{A}$ is the geometric electrode surface area $\left(1.0 \mathrm{~cm}^{2}\right)$. Furthermore, as described by Weppner and Huggins, ${ }^{19)}$ the chemical diffusion coefficient, $D$, is re-

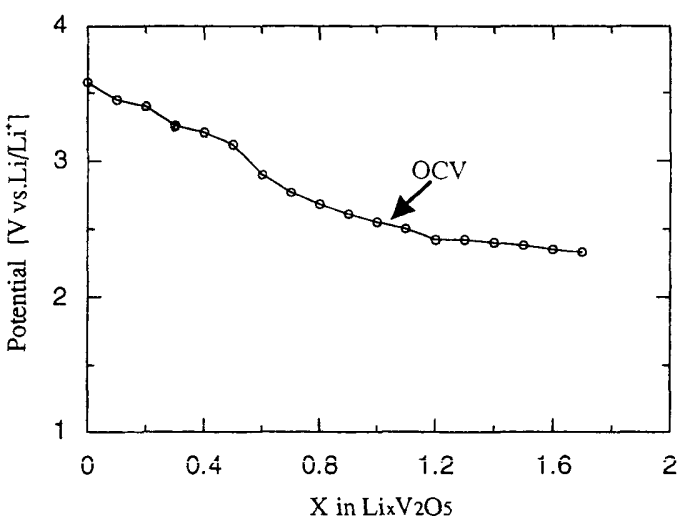

Fig. 8 Open-circuit potential as a function of $\mathrm{x}$ in $\mathrm{Li}_{\mathrm{x}} \mathrm{V}_{2} \mathrm{O}_{5}$ at $298 \mathrm{~K} . \mathrm{V}_{2} \mathrm{O}_{5}$ films as deposited with thickness of $450 \mathrm{~nm}$ were used.

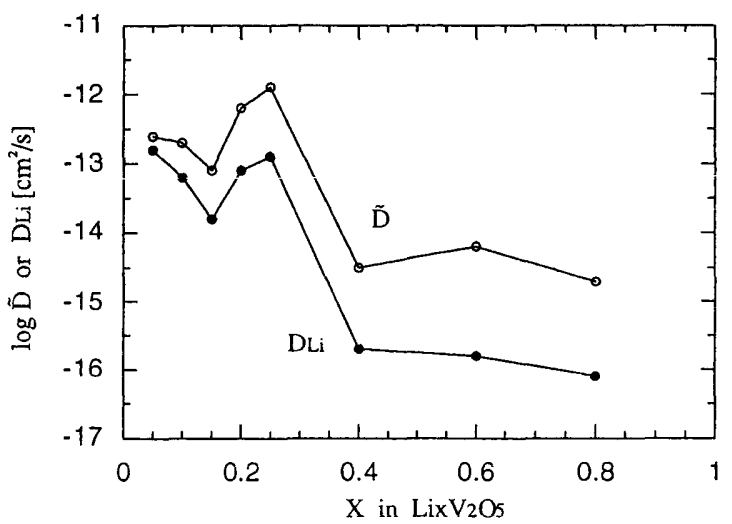

Fig. 9 Chemical $(\hat{D})$ and component $\left(D_{1 \mathrm{i}}\right)$ diffusion coefficients of lithium in $\mathrm{Lix}_{2} \mathrm{~V}_{2} \mathrm{O}_{5}$ at $298 \mathrm{~K} . \mathrm{V}_{2} \mathrm{O}_{5}$ films as deposited with thickness of $450 \mathrm{~nm}$ were used.

lated to the component diffusion coefficient for lithium, $D_{\mathrm{L}}$, by the following equation;

$$
\widetilde{D}=D_{\mathrm{Li}} \frac{d \ln a_{\mathrm{Li}}}{d \ln C_{\mathrm{Li}}}=-D_{\mathrm{Li}} \frac{F}{R T} x \frac{d E}{d x}
$$

where $\left(d \ln a_{\mathrm{Lj}} / d \ln C_{\mathrm{Li}}\right)$ is the thermodynamic enhancement factor or Darken factor, which is calculated from $(d E / d x)$, the local slope of the open-circuit potential / $\mathrm{x}$ value in $\mathrm{Li}_{\mathrm{x}} \mathrm{V}_{2} \mathrm{O}_{5}$ curve (Fig. 8).

Figure 9 shows the chemical $(D)$ and component $\left(D_{\mathrm{Li}}\right)$ diffusion coefficients for lithium at $25^{\circ} \mathrm{C}$ as a function of $\mathrm{x}$-value in $\mathrm{Li}_{\mathrm{x}} \mathrm{V}_{2} \mathrm{O}_{5}$. The $\mathrm{V}_{2} \mathrm{O}_{5}$ film as deposited with thickness of $450 \mathrm{~nm}$, which has a smooth surface, was used. As seen in the figure, $\tilde{D}$ value in the range of $\mathrm{x}=0.1 \sim$ 0.3 are found to be of the order of $10^{-13} \mathrm{~cm}^{2} \mathrm{~s}^{-1}$. In the range of $\mathrm{x}=0.4 \sim 0.8$, however, the $D$ steeply decreased to the order of $10^{-15} \mathrm{~cm}^{2} \mathrm{~s}^{-1}$. Thus, higher $\bar{D}$ value of $10^{-13} \mathrm{~cm}^{2} \mathrm{~s}^{-1}$ is found at the 1st discharge step with higher discharge potential and $\mathrm{OCV}$ of around $3.3 \mathrm{~V}$ (Figs. 5 and 8). The steep decrease in $\bar{D}$ value may be due to a phase transformation to $\gamma-\mathrm{V}_{2} \mathrm{O}_{5}$ having a highly disordered lattice arrangement. ${ }^{17)}$ The $\tilde{D}$ values are approximately in agreement with those in the $\mathrm{Lix}_{\mathrm{x}} \mathrm{V}_{2} \mathrm{O}_{5}(\mathrm{x}=$ $0.2 \sim 2$ ) thin films as deposited by r.f. sputtering, which are amorphous by X-ray measurement, and are higher than those in r.f. sputtered $\mathrm{Li}_{\mathrm{x}} \mathrm{Nb}_{2} \mathrm{O}_{5}$ film $(\mathrm{x}=0 \sim 2$ and 
$\left.10^{-14} \sim 10^{-15} \mathrm{~cm}^{2} \mathrm{~s}^{-1}\right) .{ }^{20)}$

The lithium component diffusion coefficients, $D_{\mathrm{I} \text {, }}$, were found to be of the order $10^{-14} \mathrm{~cm}^{2} \mathrm{~s}^{-1}$ in the range of $\mathrm{x}$ $=0.1 \sim 0.3$ and to be of the order of $10^{-16} \mathrm{~cm}^{2} \mathrm{~s}^{-1}$ in the range of $\mathrm{x}=0.4 \sim 0.8$. The $D_{1, i}$ value is related to the rate of random motion in the absence of concentration gradient, so that the component diffusion coefficients are approximately by one order of magnitude lower than the $D$ values. Furthermore, from the Arrhenius plots of the component diffusion coefficients for $\mathrm{Li}_{\mathrm{x}} \mathrm{V}_{2} \mathrm{O}_{5}(\mathrm{x}=0.1 \sim 0.8)$, an activation energy of $90 \sim 100 \mathrm{~kJ} \mathrm{~mol}^{-1}$ was obtained. This large activation energy for lithium diffusion is typical of diffusion in amorphous materials rather than in crystalline layered materials. ${ }^{14,20,21)}$

\section{Conclusion}

Vanadium oxide films were deposited by r.f. magnetron sputtering method using $\mathrm{V}_{2} \mathrm{O}_{5}$ target in the $\mathrm{Ar}+\mathrm{O}_{2}$ atmosphere. The increase of film thickness changed the crystallographic orientation of the $\mathrm{V}_{2} \mathrm{O}_{5}$ phase from that with the ab plane parallel to the substrate to that with the ab plane perpendicular to the substrate. The crystallographic orientation is closely associated with the surface morphology of the oxide films. The galvanostatic lithium intercalation resulted in a similar initial discharge profile with main two potential plateaus at around 3.3 and $2.3 \mathrm{~V}$ vs. $\mathrm{Li} / \mathrm{Li}^{+}$in any thin film, but the thicker film $(4.0$ $\mu \mathrm{m})$ showed more distinct discharge profile and a better cycling behavior.

The kinetic study of lithium intercalation into the oxide thin film was carried out by using the current pulse relaxation technique, deducing several kinetic parameters for lithium diffusion in the oxide film layer. The attractive reversible electrochemical properties of the vanadium oxide films should allow their use as electrode materials in all-solid-state lithium-ion batteries.

\section{Acknowledgments}

The authors thank Ms. Nobuko Kumagai for her helpful assistance in the experimental work and Mr. S. Takahashi for XRD measurement.

\section{References}

1) N. Kumagai and K. Tanno, Denki Kagaku (presently
Electrochemistry), 48, 432 (1980).

2) N. Kumagai, K. Tanno, T. Nakajima, and N. Watanabe, Electrochim. Acta, 28, 17 (1983).

3) B. Scorosati, in Modern Batteries, $2^{\text {nd }}$ ed., C. A. Vincent and B. Scrosati, Editors, chap. 7, p.199, Arnold, London (1997).

4) G. Chiarello, R. Barberi, A. Amoddeo, L. S. Caputi, and E. Colavita, Appl. Surf. Sci., 99, 15 (1996).

5) S. -H. Lee, P. Liu, C. E. Tracy, and D. K. Benson, Electrochem. Solid State Lett., 2, 425 (1999).

6) S. Lu, L. Hou, and F. Gan, J. Mat. Sci., 28, 2169 (1993).

7) J. -G. Zang, J. M. McGraw, J. Turner, and D. S. Ginley, J. Electrochem. Soc., 144, 1630 (1997).

8) K. West, B. Zachau-Christiansen, and S. V. Skaarup, Solid Stade Ionics, 57, 41 (1992).

9) J. B. Bates, N. J. Dudney, D. C. Lubben, G. R. Grunzalski, B. S. Kwak, Xiaohua Yu, and R. A. Zuhr, J. Power Sources, 54, 58 (1995).

10) J. A. Theil, E. Kusano, and A. Rockett, Thin Solid Films, 133, 122 (1998).

11) J. -C. Badot, S. Ribes, E. B. Yousfi, V. Vivier, J. -P. Perreira-Ramos, N. Baffier, and D. Lincot, Electrochem. Solid-State Lett., 3, 485 (2000).

12) R. Baddour-Hadjean, V. Golabkan, J. -P. Pereira-Ramos, A. Mantoux, and D. Lincot, J. Raman Spectrosc., 33, 631 (2002).

13) J. M. Mcgraw, C. S. Bahn, P. A. Parilla, J. D. Perkins, D. W. Ready, and D. S. Ginley, Electrochim. Acta, 45, 187 (1999).

14) N. Kumagai, H. Kitamoto, M. Baba, S. Durand-Vidal, D. Devilliers, and H. Groult, J. Appl. Electrochem., 28, 41 (1998).

15) M. Baba, N. Kumagai, H. Kobayashi, O. Nakano, and K. Nishidate, Electrochem. Solid-State Lett., 2, 320 (1999).

16) Joint Committee on Powder Diffraction Standards, 9-387.

17) C. Delmas, H. Cognac-Auradou, J. M. Cocciantelli, M. Menetrier, and J. P. Doumerc, Solid State Ionics, 69, 257 (1994).

18) S. Basu and W. L. Worrell, in "Fast ion transport in solids", eds. P. Vashista, J. N. Mundy, and G. K. Shenoy (North-Holland, Amsterdam, 1979), p.149.

19) W. Weppner and R. A. Huggins, Ann Rev. Mat. Sci., 8, 269 (1987).

20) N. Kumagai, Y. Tateshita, Y. Takatsuka, M. Baba, T. Ikeda, and K. Tanno, J. Power Sources, 54, 175 (1995).

21) N. Kumagai and K. Tanno, Electrochim. Acta, 36, 935 (1991). 